\title{
ANALISIS "SCIENCE MOTIVATION" SISWA SD SE-KECAMATAN PULOKULON, GROBOGAN TAHUN AJARAN 2018/ 2019
}

\author{
Dewi Anjarsari ${ }^{1}$, Fenny Roshayanti ${ }^{2}$, Rofian $^{3}$ \\ ${ }^{13}$ Pendidikan Guru Sekolah Dasar, Universitas PGRI Semarang, \\ ${ }^{2}$ Pendidikan Biologi, Universitas PGRI Semarang \\ Semarang, Indonesia \\ email : dewianjar369@gmail.com ${ }^{1}$, fennyrosh@gmail.com² ${ }^{2}$,kotakomik.pian@gmail.com ${ }^{3}$
}

\begin{abstract}
Abstrak
Penelitian ini bertujuan untuk mengetahui Science Motivation siswa SD Se- Kecamatan Pulokulon Tahun Ajaran 2018/ 2019 ditinjau dari aspek Science Motivation Quesionare ( SMQ) Berdasarkan Kemendikbud 2016, pencapaian pendidikan di Indonesia dibidang sains pada tahun 2015 didukung oleh 3 aspek, salah satunya adalah aspek sosial ekonomi. Hasil PISA 2015 menunjukan bahwa pendidikan orang tua siswa mempengaruhi pencapaian pendidikan sains di Indonesia. Sebagian besar orang tua siswa SD diKecamatan Pulokulon mengeyam pendidikan sampai jenjang SMP. Penelitian ini didukung oleh aspek Science Motivation Quesionare yang diadaptasi dari Glynn et. al ( 2009). Metode penelitian ini adalah kualitatif dengan teknik pengumpulan data angket, wawancara, observasi dan dokumentasi. Subjek dari Penelitian ini adalah siswa kelas V SD yang terdiri dari 217 siswa sampel dari 17 SD. Hasil dari penelitian ini menunjukkan bahwa Motivation siswa SD di Kecamatan Pulokulon, Grobogan Tahun Pelajaran 2018/2019 tergolong dalam kriteria tinggi dengan persentase 47,9\%. Dilihat dari aspek Motivation Quesionare ( SMQ) tergolong kriteria tinggi yaitu dengan skor rata- rata 103. Dari masingmasing SD di Kecamatan pulokulon diketahui dalam kriteria sangat tinggi dan tinggi pada aspek SMQ. Perbedaan kriteria tersebut dipengarui oleh beberapa faktor seperti guru, lingkungan keluarga ataupun lingkungan masyarakat.
\end{abstract}

Kata kunci: Science Motivation, Science Motivation Quesionare, Kecamatan Pulokulon

\section{Abstract}

This study aimed to determine the Science Motivation of elementary school students in the Pulokulon Subdistrict in 2018/2019 academic year in terms of the Science Motivation Quesionare (SMQ) aspects. the economy. PISA 2015 results show that the education of parents influences the achievement of science education in Indonesia. Most parents of elementary school students in Pulokulon sub-district study until junior high school. This research supported by aspects of Science Motivation Quesionare adapted from Glynn et. al (2009). This research method was qualitative with questionnaire data collection techniques, interviews, observation and documentation. The subjects of this study were fifth grade elementary school students consisted of 217 sample students from 17 elementary schools. The results of this study indicate that the motivation of elementary school students in Pulokulon District, Grobogan in the 2018/2019 Academic Year classified as high criteria with 47.9\%. Judging from the aspect of Motivation Quesionare (SMQ), it classified as a high criterion with an average score of 103. From each elementary school in Pulokulon District it is known that the criteria are very high and high on the SMQ aspect. The different criteria influenced by several factors such as teacher, family environment or community environment.

Keywords: Science Motivation, Science Motivation Quesionare, Kecamatan Pulokulon 


\section{Pendahuluan}

Berdasarkan hasil survey Tahun 2015 menunjukkan kenaikan pencapaian pendidikan di Indonesia bidang sains yang signifikan yaitu sebesar 22,1 point dalam kompetensi yang diikuti oleh 72 negara di dunia. Hasil kompetensi sains 2015 tersebut menempatkan Indonesia pada posisi ke empat dalam hal kenaikan pencapaian murid, dibanding hasil survey tahun 2012 dalam kompetensi PISA. PISA (Programme for Internasional Student Assesment ) merupakan sistem ujian yang diinisasi oleh Organisation for Economic Cooperation and Development (OECD), untuk mengevaluasi sistem pendidikan 72 negara diseluruh dunia termasuk pendidikan yang ada di Indonesia.

Menurut UUD RI Nomor 20 Tahun 2003 tentang Sistem Pendidikan Nasional,"Pendidikan adalah usaha sadar dan terencana untuk mewujudkan suasana belajar dan proses pembelajaran agar peserta didik secara aktif mengembangkan potensi dirinya,untuk memiiki kemampuan spiritual keagamaan, pengendalian diri, kepribadian, kecerdasan, akhlak mulia, serta ketrampilan yang diperlukan dirinya, masyarakat, bangsa dan negara"(Sudharto, et.al., 2009: 5

Pendidikan karakter berpijak dari karakter dasar manusia, yang bersumber dari nilai moral universal (bersifat absolut) sebagai pengejawantahan nilai-nilai agama yang biasa disebut the golden rule. Pendidikan karakter dapat memiliki tujuan yang pasti, apabila berpijak dari nilai-nilai karakter dasar tersebut. Menurut para ahli psikolog, beberapa nilai karakter dasar tersebut adalah: cinta kepada Allah dan ciptaan-Nya (alam dengan isinya), tanggung jawab, jujur, hormat dan santun, kasih sayang, peduli, kerjasama, percaya diri, kreatif, kerja keras, pantang menyerah, keadilan kepemimpinan, baik, rendah hati, toleransi, cinta damai dan cinta persatuan (Ayu, 2017).

Pencapaian pendidikan di Indonesia dibidang sains pada tahun 2015 didikung oleh 3 aspek, yaitu (1) aspek sekolah, hal ini karena adanya peranan kepala sekolah yang memiliki tanggung jawab penuh terhadap tata pengelolaan sekolah yang baik sehingga murid- muridnya tercatat memiliki prestasi tinggi dibidang sains. (2) Aspek prestasi siswa dari sekolah Negri dan Swasta. Hal ini memberikan memberikan berbedaan capaian nilai yang signifikan. Murid di Indonesia yang bersekolah Negri mencatat 16 point lebih unggung dibandingkan murid yang bersekolah diswasta dalam bidang sains. (3) Aspek sosial ekonomi, dari hasil PISA 2015 tercatat 1 dari 4 sampel responden murid di Indonesia memiliki orang tua yang hanya tamat SD. Berdasaran hasil wawancara, orang tua siswa SD di Kecamatan Pulokulon mengenyam pendidikan sampai jenjang SMP. Hal ini dapat memepengaruhi Motivation yang dimiliki siswa SD di Kecamatan Pulokulon. Pendidikan di sekolah dasar merupakan pendidikan yang masih di di imbangi dengan nasihat khusus, mengingat usia SD yang masih bersifat kenak- kanakan dan masih membutuhkan perhatian lebih. Pendidikandi SD sebagai proses pendidikan awal yang tidak hanya memberikan bekal kemampuan intelektual seperti menulis, membaca dan menghitung, namun pendidikan di SD juga mengembangkan kemampuan dasar ataupun ketrampilan yang dimiliki anak sebagai bekal untuk melanjutkan di jenjang pendidikan SLTP.

Croker dan Wolfe (2001) menyatakan Science Motivation berpengaruh terhadap perilaku siswa yang terkait dengan prestasinya dalam sains. Motivasi dapat mempengaruhi apa yang di pelajari, kapan siswa belajar, dan bagaimana siswa belajar (Schunk, 2012: 7). Belajar menunjukkan pada suatu aktivitas menuju suatu perubahan tingkah laku pada diri individu melalui proses interaksi dengan lingkungan. Sedangkan pembelajaran yang efektif ditandai dengan terjadinya proses balajar dalam diri siswa, namun dalam proses pembelajaran guru terlibat dan harus berupaya secara optimal menciptakan kondisi yang memungkinkan siswa terdorong untuk berperan aktif sebagai wujud nyata terjadinya proses belajar dalam diri siswa ( Rofian, 2016).

Menurut Donald (dalam Hamalik, 200: 158) Motivasi belajar adalah" perubahan dalam diri ( pribadi) seseorang yang ditandai dengan timbulnya perasaan dan reaksi untuk tercapai tujuan". Dalam pengertian yang dimaksud Donald tersebut, terdapat tiga unsur yang saling berkaitan antara lain motivasi dimulai dari adanya perubahan energi dalam pribadi, motivasi 
ditandai dengan timbulnya perasaan efektifitas dan motivasi ditandai dengan reaksi - reaksi untuk mencapai tujuan. Tujuan tersebut adalah sebuah karir yang diharapkan oleh siswa. Sedangkan menurut Surybrata (1984), motif adalah keadaan dalam diri seseorang yang mendorong individu tersebut untuk melakukan aktivitas-aktivitas tertentu guna mencapai tujuan yang diinginkan. Motivasi merupakan perubahan tenaga di dalam diri seseorang yang ditandai oleh dorongan afektif dan reaksi-reaksi untuk mencapai tujuan (Donald dalam Soemanto, 2012: 203). Secara umum, terdapat dua peranan penting motivasi dalam belajar, a) motivasi merupakan daya penggerak psikis dalam diri siswa yang menimbulkan kegiatan belajar, menjamin kelangsungan belajar demi tercapainya sebuah tujuan, b) motivasi memegang peranan penting dalam memberikan gairah, semangat dan rasa senang dalam belajar, sehingga siswa memiliki motivasi tinggi serta energi yang banyak untuk melakukan kegiatan belajar ( Siregar dan Nara, 2014: 51).

Dalam study yang dilakukan Fyans dan Maerh dalam ( Siregar dan Nara, 2014: 51-52), diketahui bahwa diantara tiga faktor, yaitu latar belakang keluarga, kondisi atau konteks sekolah dan motivasi, maka faktor yang terakhir merupakan prediktor yang paling baik untuk prestasi belajar. Walberg dkk. (1983) menyimpulkan bahwa motivasi mempunyai kontribusi antara 11 sampai 20\% terhadap prestasi belajar. Studi yang dilakukan Suciati (1990) menyimpulkan bahwa kontribusi motivasi sebesar 36\%, sedangkan Clelland menunjukkan bahwa motivasi berprestasi (achieverment motivation) mempunyai kontribusi sampai $64 \%$ terhadap prestasi belajar

Motivasi dapat dibedakan menjadi motivasi instrinsik dan motivasi ekstrinsik. Motivasi intrinsik adalah motivasi yang berasal dari dalam diri seorang individu tanpa adanya rangsangan dari luar, sedangkan motivasi ekstrinsik adalah motivasi yang berasal dari luar. Misalnya adalah pemberian pujian, ataupun pemberian hadiah. Motivasi intrinsik realitasnya lebih memiliki daya tahan yang lebih kuat dibanding motivasi ekstrinsik. Hal ini terjadi karena faktor ekstrinsik dapat saja justru mengakibatkan daya motivasi individu berkurang karena faktor ekstrinsik tersebut mengecewakan seorang individu ( Siregar dan Nara, 2014: 50). Science Motivation Quesioner merupakan aspek yang sangat berpengaruh pada penelitian motivation, karena aspek ini berkaitan dengan motivasi siswa dalam belajar IPA.

Science motivation adalah keadaan internal yang mengaktifkan, mengarahkan, dan menjaga perilaku belajar sains (Glynn et.al, 2011). Adanya Science Motivation pada diri siswa akan menjadi awal yang baik dalam belajar sains, setidaknya mereka memiliki kemauan maupun perilaku yang aktif untuk belajar lebih mendalam tentang sains. Science motivation mempengaruhi siswa dalam berperilaku terkait dengan prestasi mereka dalam sains. Pembelajaran IPA di Sekolah Dasar merupakan pondasi awal dalam menciptakan siswa-siswa yang memiliki pengetahuan, keterampilan dan sikap ilmiah. Pembelajaran IPA diarahkan dengan cara mencari tahu tentang alam secara sistematis, sehingga IPA bukan hanya merupakan penguasaan kumpulan pengetahuan yang berupa fakta-fakta, konsep-konsep, atau prinsip-prinsip saja, tetapi juga merupakan suatu proses penemuan dan pembentukan sikap ilmiah.

Menurut Mariana dan Praginda (2009) hakikat IImu pengetahuan Alam (IPA) merupakan makna alam dan berbagai fenomena/ perilaku/ karakteristik yang dikemas menjadi sekumpulan teori dan konsep yang melalui serangkaian proses ilmiah yang dilakukan manusia. Pembelajaran IPA di Sekolah Dasar merupakan pondasi awal dalam menciptakan siswa-siswa yang memiliki pengetahuan, keterampilan dan sikap ilmiah. Pembelajaran IPA diarahkan dengan cara mencari tahu tentang alam secara sistematis, sehingga IPA bukan hanya merupakan penguasaan kumpulan pengetahuan yang berupa fakta-fakta, konsep-konsep, atau prinsip-prinsip saja, tetapi juga merupakan suatu proses penemuan dan pembentukan sikap ilmiah.

Hal ini sejalan yang diungkapkan Widodo dalam ( Sardinah, 2012) pembelajaran sains yang hanya membelajarkan fakta, konsep, prinsip, hukum, dan teori sesungguhnya belum membelajarkan sains secara utuh. Dalam membelajarkan sains guru hendaknya juga melatih keterampilan siswa untuk berproses (keterampilan proses) dan juga menanamkan sikap ilmiah, misalnya rasaingin tahu, jujur, bekerja keras, pantang menyerah, dan terbuka. Pendidikan 
sains disekolah diharapkan dapatmenjadi wahana bagi siswa untuk mempelajari diri sendiri sengan lingkungan alam sekitarnya. Pembelajaran sains menekankan pada pengalaman langsung untuk mengembangkan potensi dalam diri siswa melalui proses " mencari tahu" dan "berbuat langsung" untuk memperoleh pemahaman yang mendalam tentang sains.

Hakikat sains dapat didefinisikan sebagai ilmu tentang alam dalam bahasa indonesia disebut dengan ilmu pengetahuan alam (Susanto, 2013: 167). IPA sebagai salah satu mata pelajaran di sekolah dasar dapat memberikan peranan penting bagi pengalaman siswa. Hasil pembelajaran IPA pun sangat dipengaruhi oleh motivasi internal maupun eksternal. Pembelajaran IPA dilakukan dengan berbagai upaya, yaitu salah satunya melalui peningkatan motivasi belajar. Dalam hal belajar siswa akan berhasil jika dalam diri siswa terdapat kemauan untuk belajar dan dorongan untuk belajar, karena dengan peningkatan motivasi belajar siswa akan bergerak, terarahkan sikap dan perilaku siswa dalam belajar. Sains atau IPA adalah usaha manusia dalam memahami alam semesta melalui pengamatan yang tepat pada sasaran, serta menggunakan prosdur, dan dijelaskan dengan penalaran sehingga mendapatkan suatu kesimpulan.

\section{Metode}

Metode yang digunakan dalam penelitian ini adalah metode penelitian kualitatif. Pengumpulan data yang digunakan yaitu angket yang meliputi angket siswa dan guru, wawancara dengan guru sampel, observasi kondisi fisik sekolah dan dokumentasi. Instrument penelitian adalah alat atau fasilitas yang digunakan oleh peneliti dalam mengumpulkan data agar pekerjaannya lebih mudah, dan hasilnya lebih baik, dalam arti lebih cermat, lengkap, dan sistematis sehingga lebih mudah di olah (Arikunto, 2010: 203). Instrument dalam penelitian menggunakan kuesioner ( angket) serta wawancara. Wawancara dilakukan dengan guru kelas $V$ secara sampel setelah penyebaran angket guru kelas di 17 SD yang memuat pertanyaanpertanyaan yang berhubungan dengan science motivation siswa.

Adapun angket siswa yang menjadi sumber data yang penting karena melalui angket yang diberikan pada siswa peneliti memperoleh data yang kemudian akan dianalisis untuk mengetahui science motivation siswa. Alat dalam penelitian ini salah satuya dengan menggunakan angket siswa yang diadaptasi dari penelitian Glynn, et. al ( 2009) dengan 25 pernyataan. Selain angket dan wawancara adapula teknik Observasi merupakan metode pengumpulan data dimana peneliti melihat dan mengamati secara visual sehingga validitas data sangat tergantung pada observer ( Basrowi dan Suwandi, 2008: 94). Teknik observasi dilakukan untuk mengobservasi atau melihat dan menilai secara langsung kondisi ruang kelas $V$ di SD yang di jadikan sampel penelitian. Dengan melakukan observasi peneliti dapat mengetahui kondisi ruang kelas dan menilai apakah ruang kelas tersebut dapat mendorong motivation siswa. . Adapun kondisi fisik yang diamati lainnya yaitu meliputi menarik / tidaknya kondisi perpustakaan bagi siswa, selain perpustakaan peneliti juga mengamati kondisi alat / media pembelajaran ipa

Subjek penelitian ini adalah kelas V SD yang berjumlah 217 siswa yang diambil dari 17 SD Sampel. Penelitian ini menggunakan teknik sampling Proportionate Stratified Random Sampling yang termasuk dalam Probability Sampling Teknik ini digunakan karena populasi mempunyai anggota / unsur yang tidak homogen dan berstara secara proposional (Sugiyono, 2017: 118 - 120). Berdasarkan teknik pengambilan sampel tersebut jumlah sampel $100 \%$ dapat mewakili populasi adalah sama dengan jumlah anggota populasi itu sendiri. Tingkat ketelitian / kepercayaan yang dikehendaki sering tergantung pada sumber dana, waktu, dan tenaga yang tersedia. Sehingga Semakin besar tingkat kesalahan maka akan semakin kecil jumlah sampel yang diperlukan, dan sebaliknya, semakin kecil tingkat kesalahan, maka akan semakin besar jumlah anggota sampel yang diperlukan sebagai data.

Terdapat kategori dalam menentukan tingkat motivation siswa yaitu kriteria sangat tinggi, tinggi, cukup, rendah dan sangat rendah. Kategori menggunakan penialaian acuan PAP yang bertujuan untuk mengukur secara pasti tujuan atau kompetensi yang ditetapkan sebagai kriteria keberhasilan untuk menentukan batas lulus (passing grade) ( Arifin, 2009: 235). 
Tabel 1. Kriteria Science Motivation Quesionare ( SMQ)

\begin{tabular}{ll}
\hline Rentang Skor & Kriteria SMQ \\
\hline $106-125$ & Sangat Tinggi \\
$86-105$ & Tinggi \\
$66-85$ & Sedang \\
$45-65$ & Rendah \\
$\geq 44$ & Sangat rendah \\
\hline
\end{tabular}

\section{Hasil Dan Pembahasan}

Berdasarkan Hasil perhitungan diketahui bahwa Science Motivation siswa se - Kecamatan Pulokulon, Grobogan Tahun Ajaran 2018/ 2019 dapat dilihat pada grafik sebagai berikut :

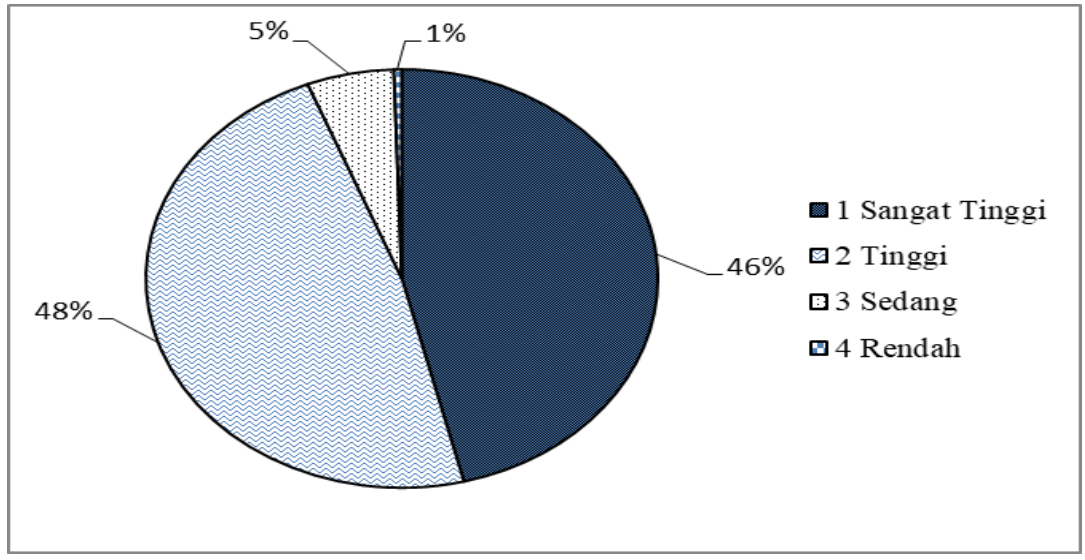

Gambar 2. Diagram persentase Science Motivation siswa SD se-Kecamatan Pulokulon

Hasil penelitian menunjukkan 48 \% siswa di Kecamatan Pulokulon memiliki Science Motivation dalam kriteria tinggi. Dalam penelitian ini terdapat salah satu aspek yang mendukung penelitian yaitu Science Motivation Quesionare ( SMQ). Secara perhitungan keseluruhan aspek SMQ di Kecamatan Pulokulon tergolong dalam kriteria tinggi yaitu dengan skor rata- rata 103. Dari masing- masing SD di Kecamatan Pulokulon diketahui SMQ siswa tergolong dalam kriteria sangat tinggi dan tinggi. Berikut adalah grafik SMQ siswa SD di Kecamatan Pulokulon dari masing- masing SD.

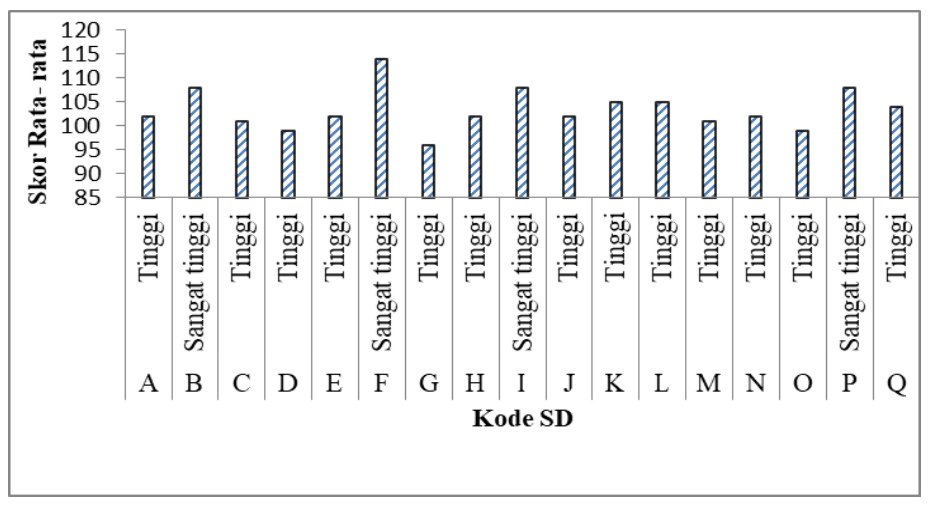

Gambar 3. Skor rata- rata aspek SMQ masing- masing SD 
Skor rata- rata tertinggi terdapat pada SD F yaitu dengan skor 114. Tingginya skor SMQ di SD F didukung oleh peran guru yang aktif. Guru berperan sebagai pengelola proses belajarmengajar, selaku fasilitator, berusaha menciptakan kondisi belajar yang efektif, dapat mengembangkan kemampuan yang dimiliki siswa untuk sesuatu yang akan dicapai ( Isjoni, 2009 : 11). Hal ini dibuktikan dengan angket guru yang menyatakan bahwa guru sering mengajak siswa untuk belajar diluar kelas, mengamati alam/ lingkungan sekitar. Selain itu guru juga sering mengadakan praktik dalam pembelajaran IPA ( AGF.En/ 9 Mei 2019). Hal ini sengaja dilakukan karena siswa di SD F banyak yang mengeluh bosan apabila pembelajaran dilakukan dengan ceramah. Siswa lebih semangat belajar apabila pembelajaran dilakukan dengan praktik. Hal tersebut dilakukan guru agar mendorong motivasi dalam diri siswa untuk belajar IPA. Usaha tersebut sesuai dengan penelitian sebelumnya yang menyatakan bahwa perilaku pembelajaran yang diperoleh siswa dari peraturan eksternal secara bertahap diinternalisasi, dan akhirnya siswa termotivasi secara intrinsik (Shin, et al, 2018).

Berdasarkan hasil penelitian terdapat pula SD yang memiliki skor science motivation terendah yaitu pada sekolah dengan kode SD G. Sekolah dengan kode SD G merupakan SD yang memiliki jumlah siswa terbanyak diantara SD lainnya ( 47 siswa). Berdasarkan hasil observasi ruang kelas di SD G terlihat sangat sempit karena jumlah siswa yang terlalu banyak sehingga ruang gerak siswa menjadi berkurang ( LO.SDG/ 10 Mei 2019). Lingkungan fisik yang tidak nyaman untuk belajar akan berdampak pada menurunnya motivasi belajar siswa ( Siregar dan Nara, 2014 : 54).

Aspek SMQ sangat berpengaruh dalam penelitian ini, karena pernyataa dalam SMQ menyangkut tentang science motivation siswa. Terdapat 25 pernyataan untuk mengetahui seberapa besar respon siswa terhadap pembelajaran IPA.

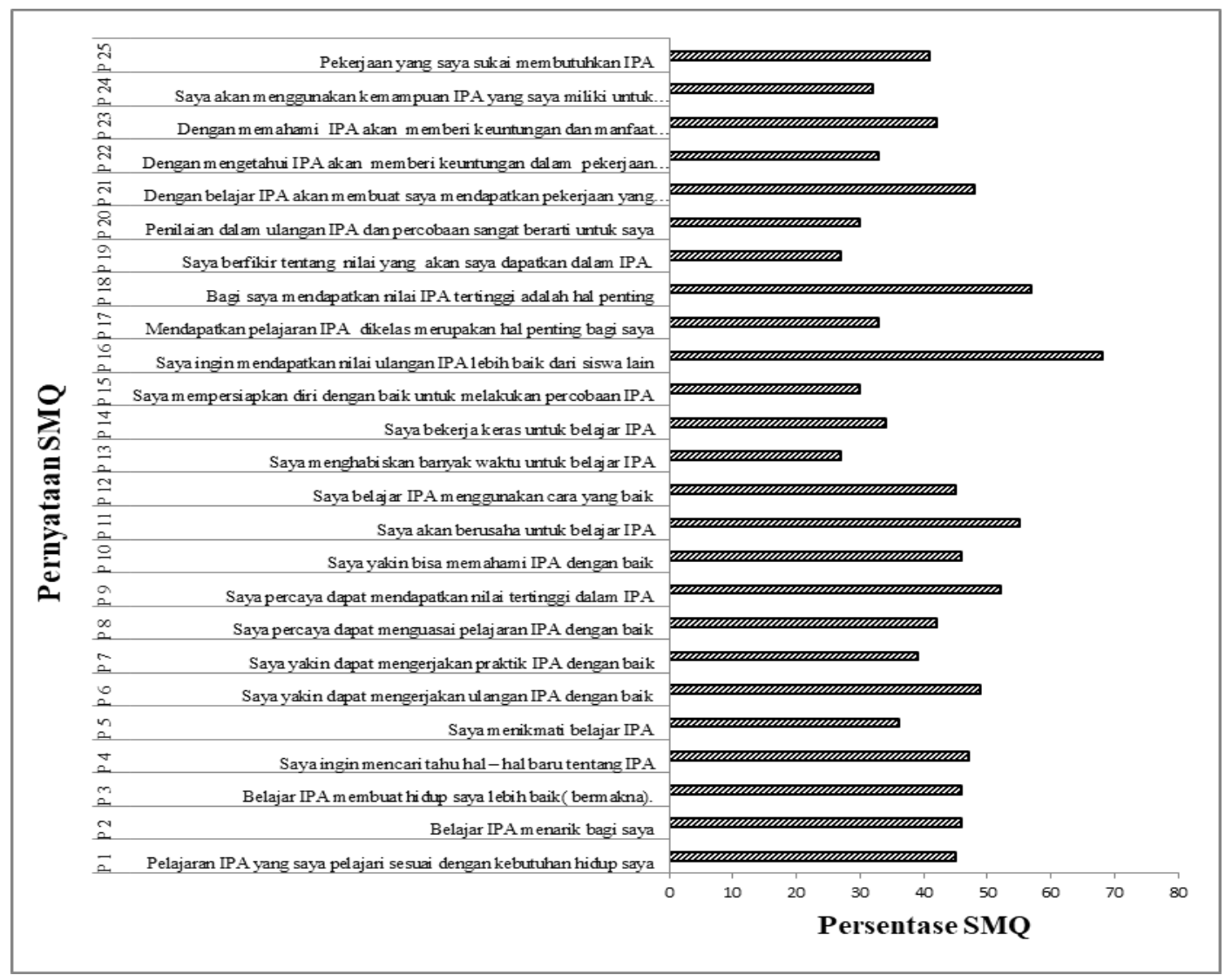

Gambar 4. Persentase jawaban setuju pada pernyataan aspek $S M Q$ 
Dari hasil angket aspek SMQ persentase tertinggi terdapat pada pernyataan No. 16 yang menunjukkan $68 \%$ siswa sangat setuju dengan pernyataan tersebut. Hal ini menunjukkan siswa SD se - Kecamatan Pulokulon inginkan mendapat nilai IPA yang lebih baik dibanding teman- temannya. Hal ini dapat dilihat pada persentase minat siswa terhadap IPA, yaitu sebesar $80,6 \%$, sehingga siswa saling bersaing untuk mendapatkan nilai IPA terbaik. Pada pernayaan No. 18 menunjukkan $57 \%$ sangat setuju dengan pernyataan tersebut. Hal tersebut menunjukkan bahwa siswa beranggapan nilai IPA tertinggi adalah hal yang penting. Dengan ambisi siswa yang tinggi untuk mendapatkan nilai tinggi dalam IPA akan menjadikan siswa terdorong atau lebih memotivasi dirinya untuk belajar yang lebih giat tentang IPA. Berdasarkan angket siswa ( ASI.Mn/ 11 Mei 2019), diketahui bahwa siswa memiliki skor SMQ tertinggi yaitu 124, selain itu siswa juga berkeinginan untuk menjadi dokter. Besarnya motivasi IPA yang dimiliki siswa tentunya menjadikan siswa ingin mendapat prestasi dalam IPA, prestasi tersebut dapat di buktikan dengan mendapat nilai tertinggi. Hal ini sejalan dengan temuan sebelumnya yang mengemukakan bahwa prestasi seseorang sangat berpengaruh pada sebuah pekerjaan yang menjadi aspek paling utama dalam meniti kehidupan baik dalam pendidikan maupun dalam perjalanan karir siswa (Komara, 2016).

Dari data angket siswa aspek SMQ pada pernyataan No. 11 menunjukkan $55 \%$ siswa sangat setuju dengan pernyataan tersebut. Hal ini menunjukkan bahwa siswa SD seKecamatan Pulokulon akan berusaha keras belajar IPA. Rata- rata siswa SD se- Kecamatan Pulokulon memiliki ketertarikan IPA yang besar. Hal ini dibuktikan dengan skor rata- rata SMQ siswa yaitu 103. Adapun usaha keras yang dilakukan siswa dipengaruhi oleh pekerjaan yang ingin dicapai. Sebesar 16,7\% siswa di Kecamatan Pulokulon memiliki keinginan pekerjaan dibidang IPA. Adanya dorongan dari pekerjaan yang menjadi tujuan, menjadikan siswa bersungguh-sungguh belajar IPA sesuai yang dikemukakan Bandura (1997) (dalam Wicaksono, et. al, 2018) yang menyatakan bahwa individu dengan self-efficacy tinggi harus juga disinkronkan untuk kinerja perilaku tertentu dan pencapaian tujuan yang diinginkan.

Dari hasil angket aspek SMQ pada pernyataan No. 8 menunjukkan $42 \%$ siswa sangat setuju dengan pernyataan tersebut.Hal ini menunjukkan siswa beranggapan bahwa dengan memahami IPA akan memberikan keuntungan dan manfaat pada pekerjaan yang siswa inginkan. Seorang siswa akan memiliki motivasi karir tinggi ketika siswa berpikir bahwa belajar ilmu nya dapat memberikan kontribusi yang besar dalam pengejaran karir siswa yang diinginkan ( Rachmatullah et. al, 2016). motivasi karir siswa SD se- Kecamatan Pulokulon tergolong kriteria tinggi. Dilihat pada data peminatan siswa yaitu 80,6\% menyukai IPA. Hal ini didukung angket salah satu siswa ( ASC. La/ 4 Mei 2019) diketahui bahwa siswa sangat menyukai IPA dengan alasan karena pelajaran IPA bisa bermanfaat dalam pekerjaan siswa ( Arsitek).

Berdasarkan pernyataan SMQ pada pernyataan No. 13 menunjukkan $27 \%$ siswa sangat setuju dengan pernyataan tersebut. Pernyataan ini merupakan pernyataan dengan persentase terendah dibanding pernyataan lainnya. Hal ini menunjukkan bahwa banyak siswa yang tidak menghabiskan banyak waktu untuk belajar IPA. Rendahnya persentase pada pernyataan ini bertolak belakang dengan persentase pernyataan sebelumnya, yaitu $57 \%$ siswa menganggap bahwa mendapat nilai IPA tertinggi itu penting. Upaya yang tinggi dalam pembelajaran dan kognisiakan menghasilkan efektifitas yang tinggi dalam pembelajaran termasuk hasil belajar ( Wicaksono, 2018). Hal ini dapat dikarnakan kurangnya fasilitas untuk belajar IPA. Dari hasil Observasi di salah satu SD ( LO. SDM/ 14 Mei 2019), dapat diketahui bahwa di SD tersebut tidak terdapat perpustakaan. Hal ini menjadikan siswa kurang mendapat informasi tentang IPA. Siswa hanya memperoleh pengetahuan IPA saat pembelajaran di kelas. Kurangnya prasarana di sekolah menjadikan siswa tidak menghabiskan waktunya untuk belajar/ mencari informasi di luar pembelajaran di kelas. Dengan kondisi seperti ini menuntut guru agar lebih banyak melibatkan siswa dalam hal IPA.

Dari hasil angket SMQ pada pernyataan No. 14 dan 19 menunjukkan $29 \%$ siswa cukup setuju dengan pernyataan tersebut. Hal ini menunjukkan siswa SD se- Kecamatan Pulokulon tidak meyakini penuh bahwa dirinya berfikir keras tentang IPA dan memikirkan nilai IPA yang akan didapatkan. Berdasarkan salah satu angket siswa ( ASD. No/ 8 Mei 2019) diketahui 
bahwa siswa tidak memikirkan nilai IPA yang akan diperoleh. Dilihat dari pekerjaan yang akan dicapai siswa adalah seorang dokter. Hal ini merupakan ketidak seimbangan antara pekerjaan yang diharapkan dengan motivasi yang dimiliki siswa. Pekerjaan dokter merupakan pekerjaan yang harus memiliki potensi atau motivasi lebih terhadap IPA. Perencanaan karir adalah suatu proses pemilihan karir dengan menyeimbangkan bakat, minat dan potensi yang dimiliki siswa ( Komara, 2013). Pada hal ini guru harus lebih mengarahkan siswa tentang pekerjaan yang ingin dicapai dan usaha yang harus dilakukan siswa, mengingat dokter adalah pekerjan yang membutuhkan motivasi tinggi terhadap IPA. Guru harus lebih mengarahkan bahwa untuk menjadi dokter harus belajar giat dan mendalami pelajaran IPA untuk mencapai pekerjaan yang diharapkan.

Pada pernyataan No. 24 Sebesar 1,3 \% siswa SD Se- Kecamatan Pulokulon sangat tidak menyetujui pernyataan tersebut. Hal ini menunjukkan bahwa tidak semua siswa beranggapan bahwa kemampuan IPA yang dimiliki digunakan untuk memecahkan masalah dalam pekerjaannya. Selain itu 1,8 \% siswa juga sangat tidak setuju pekerjaan yang mereka pilih membutuhkan IPA. Hal ini dapat dikarnakan $17 \%$ siswa memilih pekerjaan pada bidang IPS, selain itu hasil data peminatan siswa juga menunjukkan bahwa $18 \%$ siswa minat pada IPS dan 1, $4 \%$ tidak minat terhadap IPA/ IPS( Non- IPA/ IPS). Dari data tersebut diketahui beberapa siswa memiliki minat di luar IPA/ IPS, misalnya adalah penjaskes. Berdasarkan angket siswa ( ASG. An/ 10 Mei 2019) siswa tidak menyukai pelajaran IPA/ IPS, hal ini diihat dari pekerjaan yang diharapkan siswa yaitu Altet. Berdasarkan wawancara dengan siswa (WSG. An/ Mei 2019) di dapatkan informasi bahwa siswa lebih menyukai olahraga, karna pekerjaan yang ingin dicapai adalah menjadi seorang atlit, sehingga tidak suka IPA/ IPS. Berkaitan dengan keminatan siswa terhadap IPA menyebabkan skor aspek SMQ yang rendah pada siswa yaitu 60 atau $48 \%$ keminatan siswa dalam aspek SMQ.

\section{Simpulan dan Saran}

Berdasarkan penelitian yang telah dilakukan, dapat di simpulkan bahwa Motivation SD Se- Kecamatan Pulokulon dilihat dari aspek Science Motivation Quesionare (SMQ) tergolong dalam kriteria tinggi yaitu dengan skor rata- rata 103. Dari 17 SD yang dijadikan sampel terdapat 4 SD tergolong dalam kriteria sangat tinggi dan 13 SD dengan kriteria tinggi.

1. Bagi Guru : Science Motivation di Kecamatan Pulokulon sudah tergolong dalam kriteria tinggi, namun dilihat pada masing- masing SD terdapat SD yang memiliki kriteria sangat tinggi dan tinggi. Oleh karena perlu adanya pemerataan peran guru dengan meningkatkan kualitas pembelajaran yang berkaitatan dengan lingkungan ( alam).

2. Bagi Sekolah : Sekolah diharapkan dapat mendukung pemerataan tingkat motivation siswa dengan menyediakan fasilitas berupa sarana dan prasarana terkait IPA yang memadai.

3. Bagi Pemerintah, dengan adanya penelitian motivation diharapkan pemerintah pendidikan setempat dapat memperhatikan Science Motivation di Kecamatan Pulokulon dengan mengadakan sosialisasi para guru dengan tujuan untuk mendukung pemerataan Science motivation di Kecamatan Pulokulon agar mencapai kriteria maksimal.

\section{Daftar Rujukan}

Arifin, Zainal . 2016. Evaluasi Pembelajaran. Bandung : Remaja Rosdakarya.

Arikunto, Suharsimi. 2010. Prosedur penelitian suatu pendekatan praktik. Jakarta : Rineka Cipta.

Ayu, Nanda. 2017. Pendidikan Karakter Sebagai Pilar Pembentukan Karakter Bangsa. Fakultas Ilmu Sosial Universitas Negeri Medan Tahun 2017 Vol. 1 No. 1 2017, Hal. 348352 
Basrowi \& Suwandi. 2008. Memahami Penelitian Kualitatif. Jakarta: Rineka Cipta.

Croker, J \& Wolfe. C. 2001. Contingencies Of Self- Worth. Psychological Review. 108,3 , 598623

Glynn, S. M. et. al . (2009). "motivation questionnaire: Construct validation with nonmajors". Journal of Research in Teaching. Vol 46(2).

Hamalik, Oemar. 2011. Proses Belajar Mengajar. Jakarta: Bumi Aksara.

Isjoni. 2009. Guru sebagai Motivator Perubahan. Yogyakarta : Pustaka Pelajar

Kemendikbud. 2016. "Peringkat dan capaian PISA Indonesia mengalami peningkatan 06 Desember 2016". Online (https://www.kemdikbud.go.id/main/blog/2016/12/peringkatdan-capaian-pisa-indonesia-mengalami-peningkatan) Diakses 15 Desember 2018.

Komara, Indra Bangkit. 2016 ." Hubungan antara Kepercayaan Diri dengan Prestasi Belajar dan Perencanaan Karir Siswa". Psikopedagogia. Vol 5 (1).

Rachmatullah, A. et.al . (2018). " The Secondary-Student Lear ". EURASIA Journal of Mathematics, and Technology Education. Vol 14(7)..

Rofian. 2016. Penerapan Metode Pembelajaran Demostrasi Pada Pendidikan Seni Rupa Di Sekolah Dasar. Malih Peddas. Volume 6 Nomor 2 Desember 2016

Sardinah, et.al. 2012. "Relevansi Sikap Ilmiah Siswa Dengan Konsep HakikatSains Dalam Pelaksanaan Percobaan Pada Pembelajaran IPA di Sdn Kota Banda Aceh". Jurnal Pendidikan Serambi IImu, Edisi September 2012, Vol 13 (2).

Schunk, D.H. et. al. 2012 . Motivasi Dalam Pendidikan. Indeks. Jakarta.

Shin, Shein. et al. (2018). "Career motivation of secondary students in STEM:a cross-cultural study between Korea and Indonesia". Int J Educ VocatBimbingan (2018) 18: 203-231

Siregar, Evelin dan Hartini Nara. (2014). Teori Belajar dan Pembelajaran. Bogor: Ghalia Indonesia.

Sudharto, et.al. 2009. Pengantar Ilmu Pendidikan. Semarang : FIP IKIP PGRI Semarang

Sugiyono. (2017). Metode Penelitian PendidikanPendekatan Kuantitatif, Kualitatif dan R\&D. Bandung : Alfabeta.

Susanto, Ahmad. (2013). Teori Belajar \& Pembelajaran di Sekolah Dasar.Jakarta : Prenadamedia Group.

Wicaksono, Azizul Ghofar Candara . e $t$ al .2018. "Analysis Of Students' Motivation And Nature Of Comprehension In Middle School". Indonesian Journal of Biology Educatio. Vol 4 (1) 